\section{B A Institute of \\ YK Business Administration \\ 六下 \\ Karachi \\ Leadership and Ideas for Tomorrow}

Business Review

Volume 7 Issue 2 July-December 2012

7-1-2012

\title{
Business management and ethics: An Islamic approach
}

M. M. Maishanu

Usmanu Danfodiya University Sokoto, Nigeria

Ahmad Maigari Dutsin-ma

Usmanu Danfodiya University Sokoto, Nigeria

Follow this and additional works at: https://ir.iba.edu.pk/businessreview

Part of the Business Administration, Management, and Operations Commons, and the Islamic Studies Commons

c) (i)

This work is licensed under a Creative Commons Attribution 4.0 International License.

\section{Recommended Citation}

Maishanu, M., \& Dutsin-ma, A. M. (2012). Business management and ethics: An Islamic approach. Business Review, 7(2), 113-118. Retrieved from https://doi.org/10.54784/1990-6587.1208

This article is brought to you by iRepository for open access under the Creative Commons Attribution 4.0 License and is available at https://ir.iba.edu.pk/businessreview/vol7/iss2/9. For more information, please contact irepository@iba.edu.pk. 


\title{
DISCUSSION
}

\section{Business Management and Ethics: An Islamic Approach}

\author{
M. M. Maishanu \\ Usmanu Danfodiya University Sokoto, Nigeria \\ Ahmad Maigari Dutsin-ma \\ Usmanu Danfodiya University Sokoto, Nigeria
}

\begin{abstract}
This paper explores the relationships between business management and ethics in Islam. The paper's central theme is that business management is not separate from ethics; the latter reinforces the former. In Islam, mundane and spiritual pursuits are complementary as such mundane activities are not left to chance but guided by sharia to enhance the chances of spiritual salvation. To establish this, the paper largely relies on the Holy Quran and Hadith and other complementary sources of data. Istikhlaf (vicegerency), Tauhid (Oneness and Uniqueness of Allah) and ukhuwah (Brotherhood) are regarded as the main guiding concepts or precepts behind activities which a Muslim undertakes and should guide business activities and behavior of businessmen. The paper based on the sharia examines certain ethical issues in business activities such as indulging in interest-related activities, leadership (management) based on ignorance, dishonesty, profiteering, bribery etc. and their prohibition. Finally, Islamic banking which abhors interest and makes halal funds available for business growth and expansion is recommended.
\end{abstract}

Keywords: Ethics, sharia, riba,

\section{Introduction}

Business is an important aspect of man's pursuit. The nature of business in an Islamic society differs from that of a non-Islamic one. Islam is a complete way of life, and this therefore necessarily includes the business sphere. Prophet Muhammad (SAW) particularly emphasized that honesty and kind dealings with customers are the secrets of success in business. He said, "The truthful and honest merchant is associated with the Prophets, the upright and the martyrs" (Al-Tirmidhi). In another hadith, "God shows mercy to a person who is kindly when he sells, when he buys and when he makes a claim" (Al-Bukhari). The Prophet gave many teachings on business and economic issues particularly on ethical dimension; he covered almost every aspect of business and economics.

This paper shows the main principles of Islam like the concept of khilafah or istikhlaf (vicegerency), tauhid (the science of oneness and uniqueness of Allah), and ukhuwah (international Islamic Brotherhood or the Islamic globalization) and examine their linkages and shape in business undertakings. The paper also examines how a manager is supposed to ethically conduct his business dealings in Islam. The paper draws conclusions and offers some suggestions on the importance of establishing Islamic 
banking institutions for the progress of Muslims and non-Muslim communities as well in promoting ethical business dealings.

\section{Business Management in Islam}

Business is defined as an organization which operates economic activities for satisfying social and consumer needs at a profit. It also refers to all activities which are involved in the attempt to create and enhance distribution and consumption of goods and services for private and public benefits in human societies. Business is a form of activity pursued primarily with the object of earning profit for the benefit of those on whose behalf the activity is conducted. It involves production and/or exchange of goods and services to earn profits or in a broader sense, to earn a living. Profit is not the sole objective of the business but the most primary. It may have other objectives like promotion of welfare of the workers and the general public (social responsibility).

In an Islamic set up, business is neither individualistic giving emphasis only to individual nor socialistic giving emphasis to society alone per se but a balanced framework between personal and social benefits. Allah the Most High commanded man (more specifically referring to the rich like Aaron during the time of Prophet Moses) that "But seek, with that (wealth) which Allah has bestowed on you, the home of the Hereafter, and forget not your portion of legal enjoyment in this world, and do good as Allah has been good to you, and seek not mischief in the land. Verily, Allah likes not the Mufsidun (those who commit great crimes and sins, oppressors, tyrants, mischief-makers, corrupt" (Surah 28:77).

Islam emphasizes the balancing of right and risk-taking. Islam stands for perfectly balanced way of life avoiding extremism and shortages of all kinds. An Islamic community is described by Allah the Most High as a perfectly balanced one: "Thus We have made you [true Muslims - real believers of Islamic Monotheism, true followers of Prophet Muhammad and his Sunnah (legal ways)], a Wasat (just) (and the best) nation,...... (See Qur'an 2:143).

Man is a combination of matter and spirit and both require due attention. He is supposed to direct his material and spiritual pursuits toward acquiring the pleasure of Allah. The Quranic Verse 28:77 referred to above commands the Muslims to seek their livelihood with a view to getting a better and more lasting life in the Hereafter; they are also enjoined not to forget their portion of this world.

\section{Shaping Business Undertakings in Islam - Istikhlaf, Tauhid and Ukhuwah}

Istikhlaf, Tauhid and ukhuwah are the main guiding concepts or precepts behind activities which a Muslim undertakes. Tauhid means simply belief in the Oneness and Uniqueness of Allah. He is the only one worthy of being worshipped, obeyed and paid obeisance in whatever sense and not associating partners unto Him whatsoever. In addition, worship should strictly be observed as taught by His Messenger (PBUH). A Muslim must know that in order to run a successful life, creed wise or spiritually, politically, morally, socially and business wise and in fact all other facts of life, he has to give Allah's law or shariah its absolute right of obedience and implementation and not any other law whatsoever.

Istikhlaf or Khilafah goes hand in hand with Tauhid. The concept of Khilafah or vicegerency of Allah's law is also very important where man and jinn are supposed to 
represent the shariah in all aspects of life as (trust) which they promised to shoulder when they come to this terrestrial world which is the primary and the sole consideration for creating.

These two concepts permeate all the teachings of Islam and therefore must be given absolute attention in all what one does in order to get Allah's pleasure and recompense here and hereafter. One is expected to run one's business life in accordance with Islamic teaching based on the spiritual, moral, political, social, and in whatever aspects. For example, in the same way that a Muslim is expected to observe his rituals prayer, fast etc., as stipulated in the Quran and Sunnah, business conducts should be observed likewise. Otherwise, one is considered a rebel and not a real believer.

Ukhuwah is another central and basic concept in Islam. This means that whatever dealings a Muslim is going to engage in, he has to give Islamic brotherhood a very top consideration whereby he treats his fellow Muslims in accordance with the shariah and in accordance with what he himself like others to do unto himself. This is because the noblest prophet Muhammad said 'none of you is really a believer until he loves for his brother what he loves for himself' (Imam Bukhari). It is natural that no one will like or love evil for himself. In fact, in terms of dealing, it is even haram (prohibited) to cheat a non-Muslim let alone a brother Muslim.

\section{Business Ethics: Secular and Islamic Perspective}

Ethics is defined as the set of moral principles that distinguish what is right from what is wrong; it describes what one should do or abstain from doing. Business ethics, sometimes referred to as management ethics or organizational ethics, simply limits its frame of reference to organisations (Beekun:2001). Beekun (2001) adds that within an Islamic context, the term most closely related to ethics in the Quran is khuluq. The Quran also uses a whole array of terms to describe the concept of goodness: khayr (goodness), birr (righteousness), qist (equity), 'adl (equibilibrim and justice) etc.

The aim of business in a secular society differs from that of an Islamic one. In the latter, even mundane activities are designed to achieve spiritual welfare. This naturally demonstrates the differences in approach and objectives behind business pursuits in the two settings. Secularism preaches the non-inclusion of religion or spiritual values in all aspects of human life, even where they are involved; one finds that it is a mere formality. In Islamic societies like Saudi Arabia, the concept of accountability directs the attention of a businessman so that he strives with his might and main to please Allah by being just and fair to himself, his relations, and other parties to the exchange as he interacts in the market.

In an Islamic economy/business setting, there should be sincere urge from a manager to discharge his duties as a trust (amanah) from Allah. That is why all the stakeholders in all spheres of the Muslim society from a leader, a subject, a household, husband and wife, master and servant to a manager and his subordinates etc. are considered each a shepherd and will be responsible for his flock. This is similar to a cattle or animal rearer who is considered as a shepherd (a leader) and will be asked about your flock in the hereafter. Therefore, everybody under an Islamic business organisation is a trust and should be treated as such. Prophet Muhammad said "be kind to those on earth and He who is in the Heaven will be kind to you" (Tirmithi and Abu Dawud. See also 
Mushkat Vol. 2 p. 608 Hadith no. 4969). Any leadership or managerial position is a trust and the subordinates also are a trust in the hands of the leader or manager.

A Muslim manager must be knowledgeable enough to know how to run the organisation and should know the rights of those he interacts with. The issue of knowledge is very important since Islam emphasizes that leadership should not be given to an ignorant person. Islam was the first force to fight ignorance and backwardness. The first revelation in sura-al alaq commanded the Prophet Muhammad to read and do that in the name of Allah, the most Bounteous - "Read! In the Name of your Lord, Who has created (all that exists)" (Quran, 96:1). This shows that one should seek knowledge of an affair before undertaking it. Islam is the prime motivator towards progress and prosperity for the first generation of the ummah (community). The companions showed reality practically where the jahiliyyah (ignorant) Arabs were turned in less than a century unto the most progressive and most civilized nation or community mankind had ever witnessed. If in an organizational setting trusts are given to the ignorant, both the right of Allah and that of his fellow beings will be trampled upon.

In an Islamic setup, businessmen and women should try as far as possible to present their commodities or their honest descriptions so as to leave no doubt to the customer. They should avoid deceit and exaggeration so that the Hadith 'whoever deceives others is not of us' would not apply upon them. The Prophet (PBUH) said 'the seller and the buyer have the right to keep or return the purchased goods as long as they have not departed. Again, 'if both parties spoke the truth and described the defects and quality (of the goods), then they would be blessed in their transaction and if they lie or hide defects, then the blessings of their transaction would be lost' (Imam Bukhari and Imam Muslim). Therefore, adverts and activities of commercial (marketing) managers should be critically examined. The presentation of nude and attractive women folk in different fashions so as to take the unwary customer into confidence of purchasing their commodities should be checked so as not to inculcate superficial desires into their minds especially television adverts and billboards.

A business manager should not aim at profit at all cost for this has the tendency of making the business a dirty one where survival of the fittest becomes the norm. According to the Prophet (PBUH), "one of you is not a real believer till he loves for his brother what he loves for himself” (Bukhari and Muslim). This does not mean that Islam is against profit in business pursuits or dealings but moderation in all its affairs is what it calls for and preaches. Islam did not specify a quantitative level to the extent of material growth of the Muslim Ummah, since the quest for spiritual fitness is equated with that of material means. The Quran says "Then when the (Jumu'ah) Salat (prayer) is finished, you may disperse through the land, and seek the Bounty of Allah (by working, etc.), and remember Allah much, that you may be successful” (62:10). This verse contains the call made to the believers to disperse in the land and seek the bounties of Allah after offering the prayers. This does not mean the two are perfectly equalized, but in terms of commandments, the calls to both are equalized.

It is through this that the gaining of mastery over the earth and harnessing of its resources to meet the needs of the individuals and society could be possible. Islam aims at removing hardships and promoting easiness. Allah the glorified, the Most High says that: Allah desires to alleviate your burden for man is created weak. The same idea was also given elsewhere in the Quran (see Quran 2:185). The Prophet (PBUH) says "there is nothing wrong in wealth for him who fears Allah (silsilat al ahadith of Shyukh Albani). 
A Muslim manager should not allow his organization to run on usury or interest (riba), for any edifice built up thereon is bound to perish and crumble. This further enhances the exploitation of some part of the society against the other as is witnessed now in the conventional banking system. Allah the Most High has permitted trade and forbidden usury or interest dealings (Al-Quran 2:275). Dealing in usury is equated with fighting against Allah and His Prophet (PBUH) (see Quran 2:279) and in Surah Rum 30:39, Allah the Most High says "the riba that is practiced to increase some people's wealth does not gain anything at God. But if people give to charity, seeking God's pleasure, these are the ones who receive their reward many fold”. Thus, usury was deprived of all blessings but charity is multiples in blessings. Increase in volume does not mean increase in blessings in so far as usury is concerned.

Bribery and exploitation should not be condoned by a business manager in all their ramifications. People's wealth should not be allowed to go in vanity and falsehood (see Al-Quran 2:267 among others). A business management always strives to bring something new and beneficial to the society by encouraging and welcoming new ideas, views as well as giving room for new inventions and innovations in line with the Hadith the best of mankind is he who brings the most benefit to others.

Islam preaches patience, perseverance and hard work as nothing good will mature except through struggle and hard work. Allah (SWA) said "man can have nothing but what he strives for; that (the fruits of) his striving will soon come in sight" (Al-Quran 53:39-40).

\section{Conclusions}

A Muslim manager should uphold these teachings and set-up rules and regulations that are in accordance with the teachings of Islam. He should make allowance to himself and his subordinates for the performance of their daily prayers and other rituals. Business pursuits should not deter one from performing religious duties especially attending congregational prayers (see 24:37-38), keeping of promises, discharging of trusts and speaking the truth (see Al-Quran 2:177; 23:8, see also 70:32-33.

Trade and merchandize should not deter one from the remembrance of Allah. The best leaders and managers are those described in the Quran. They are those who establish prayer, give regular charity, enjoying the right and forbid the wrong” (Al-Quran 22:41).

There are certain strategies for promoting enterprises in the business sector and the economy in Islam. One strategy could be by introducing the Islamic economic system which eliminates all interest bearing in production, and by proportionately compensating entrepreneurs' risk taking behavior especially through mudarabah. Other strategies include introduction of qard hasanah (beautiful interest free loans), eliminating gambling and other dubious as well as of eliminating israf (prodigality) and stinginess in the pursuits of business.

Muslim countries and non-Muslim countries should strive to establish Islamic banks which are interest free and based on the principles, aims and objectives of the shariah. According to ITC (2009), Islamic banking represents an interesting complement or alternative to conventional banking. For some however, using Islamic finance is closely linked to the desire to follow the laws of sharia in business activities. But there are other aspects of Islamic banking that can make it attractive to a wider group, including micro, 
small and medium-sized companies. Islamic banking emphasizes the partnership relationship, where success is rewarded and failures shared.

Islamic banking however is not recent; it emerged as early as the 8th century. Islamic banking developed financial instruments that influenced the banking system in Europe in medieval times, such as bills of exchange, the first forms of partnership, limited partnerships, cheques and promissory notes (ITC:2009). Establishing Islamic banks will serve very well in the business sphere as confirmed from the prosperity and growth of existing Islamic Banks across the world. Businesses whose foundation is interest-free and based on Islamic principles like mudarabah (silent partnership agreement) should also be established and promoted. 寀

\section{References}

Beekun R. I. (2001), Islamic Business Ethics, The International Institute of Islamic Thought, Nigeria Office, Bayero University, Kano

Bukhari, I. Sahih-al-Bukhari, Lebanon, Beirut, Dar-al-Arabiyya n-d

Dawud A., Sunan Abi Dawud, ma’sharh: Aunul Marbud, Lebanon: Beirut Dar-al-fikr, n.d.

International Trade Centre (ITC) (2009), Islamic Banking - A Guide for Small and Medium-Sized Enterprises, Palais des Nations, 1211 Geneva 10, Switzerland

Interpretation of the Meanings of The Noble Quran Published by Dar-us-Salam Publications, www.Dar-us-Salam.com.

Majah Ibn, (1975), Sunan Ibn Majah, Egypt: Cairo Ihya'al-Turath al-arby, 1395 A.H. Mdadiyyah

Muslim, I.,, Sahil Muslim, Lebanon: Beirut Dar-al-fikr n.d

Tirmidhi, I., Sunan al-tirmidhi, Lebanon: Beirut, Dar-al-fikr n.d.

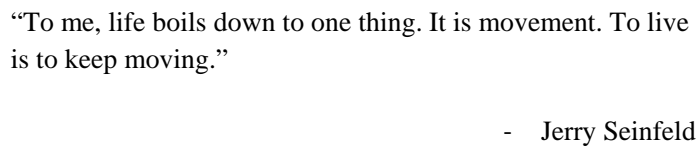

